\title{
Testicular torsion in the medicolegal perspective: Why is the diagnosis missing?
}

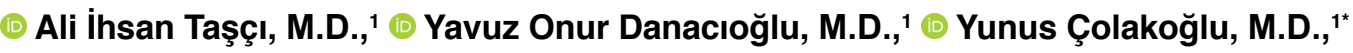

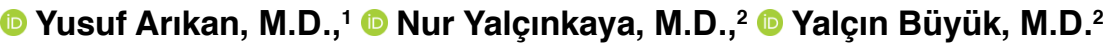

\author{
${ }^{1}$ Department of Urology, Bakirköy Dr. Sadi Konuk Training and Research Hospital, İstanbul-Turkey \\ ${ }^{2}$ Forensic Medicine Institute of the Republic of Turkey, İstanbul-Turkey
}

\begin{abstract}
BACKGROUND: By examining patients with testicular torsion (TT) that caused problems in medicolegal terms, the present study aims to define markers causing medical neglect or malpractice in similar conditions and perform a retrospective examination to characterize the medical aspects of patients with TT.

METHODS: In this study, 53 patients who underwent orchiectomy for TT following interventions made between 2004 and 2019 in different hospitals of Turkey and had satisfactory clinical findings in their files based on medicolegal inspections were included.

RESULTS: The median age of the patients was nine years. Twenty-three (43.4\%) of the patients had TT on the left side, 29 (54.7\%) had TT on the right side, and one (I,9\%) patient had bilateral TT. It was noticed that 3 I (58.5\%) patients had epididymo-orchitis (EO), seven patients had (13.2\%) urinary infection, five $(9.4 \%)$ patients had a hydrocele, and four (7.5\%) patients had renal colic, and the others had testicle contusion, gastroenteritis, inguinal hernia, and acute appendicitis as misdiagnoses. The mean time that passed between admission and TT diagnosis was detected as $59 \pm$ I I.2 hours. A statistically significant relation was detected between the branch of the physician who first evaluated the patients and the presence of performing scrotal examination and imaging during admission. The ratio of physical scrotal examinations by emergency service physicians was lower than with the urologists. Among the preliminary examiner allowed to be an advanced evaluation for the possibility of missing diagnosis by an independent specialist physicians, 25 (47.2\%) were urologists, 22 (4I.5\%) were emergency service physicians, four (7.5\%) were pediatricians, and two (3.8\%) were radiologists.
\end{abstract}

CONCLUSION: Physicians should perform the required evaluations for a suitable diagnosis and treatment by putting aside their medicolegal concerns and prevent the problems by giving priority to patient health. For the correct diagnosis and proper management of TT, it is necessary to increase the information levels of physicians, and patients should be explored urgently in the event of any clinical suspicion.

Keywords: Acute scrotum; malpractice; medicolegal; misdiagnosis; testicular torsion.

\section{INTRODUCTION}

Testicle torsion (TT) is a urologic emergency that causes the deterioration of testicular blood supply due to the spermatic cord turning around itself. Its incidence was 4.5/100.000 in males aged under 25 years, constituting $10-15 \%$ of acute scrotal pathologies. ${ }^{[1,2]}$ Definitive diagnosis from other scrotal pathologies should be made quickly because the treatment requires surgical intervention, and there is the possibility of organ loss in the end. Most of the time, history and physical examination are enough to diagnose TT. However, diagnostic imaging methods are also frequently used due to doubts about the diagnosis and unnecessary surgical intervention risk. Although scrotal color Doppler ultrasonography (CDU) is helpful for diagnosis, the possibility of false negativity and variable availability create a problem in clinical practice. ${ }^{[3]}$

Cite this article as: Taşçı Aİ, Danacıoğlu YO, Çolakoğlu Y, Arıkan Y, Yalçınkaya N, Büyük Y. Testicular torsion in the medicolegal perspective: Why is the diagnosis missing? Ulus Travma Acil Cerrahi Derg 2021;27:207-213.

*Author's new institution: Department of Urology, Başaksehir Çam and Sakura City Hospital, İstabul-Turkey

Address for correspondence: Yunus Çolakoğlu, M.D.

Bakırköy Dr. Sadi Konuk Eğitim ve Araştırma Hastanesi, Üroloji Kliniği, İstanbul, Turkey

Tel: +90 212 - 414 71 71 E-mail: dr.yunusc@gmail.com

Ulus Travma Acil Cerrahi Derg 2021;27(2):207-2I3 DOI: 10.14744/tjtes.2020.68339 Submitted: 14.01.2020 Accepted: 12.04.2020

Copyright 2021 Turkish Association of Trauma and Emergency Surgery 
The preservation of the affected testis is directly related to ischemia time. Timely diagnosis and treatment increase the possibility of preserving the testicle. ${ }^{[4,5]}$ Early diagnosis and treatment of torsion are vital for preserving testicular viability and fertility, but delayed torsion diagnosis and surgical interventions result with $31-42 \%$ testicle loss. ${ }^{[6]}$ Thus, delays and deficiencies in the diagnosis and treatment phase constitute a problem both in clinical and medicolegal terms. ${ }^{[7]}$

The diagnosis and treatment phase of TT was the third most common cause of malpractice in adolescent males aged between 12 and 17 years in the United States. ${ }^{[8]}$ Studies about the medicolegal aspects of TT are very limited in the published literature. By examining patients with TT that caused problems in medicolegal terms, the present study aims to define markers causing medical neglect or malpractice in similar conditions and to perform a retrospective examination to characterize the medical aspects of patients with TT.

\section{MATERIALS AND METHODS}

Data for patients with TT examined for medical malpractice were retrospectively evaluated by examining case files in the Council of Forensic Medicine of the Turkish Republic after taking the required permissions (21589509/2019/686). In this study, 53 patients who underwent orchiectomy for TT following interventions made between 2004 and 2019 in different hospitals of Turkey and had satisfactory clinical findings in their files based on medicolegal inspections were included. The Forensic Medicine board's opinions and personal/private information of the patients and surgeons in the files were not evaluated.

Demographic data, admission symptoms, accompanying symptoms, pre-diagnoses, whether a physical examination was made, physical examination characteristics, diagnostic imaging method performed and its characteristics, the features of the physician who evaluated the case at the first ad- mission, findings and evaluations of other physicians consulted, imaging findings and evaluations of the physician if imaging was performed, the specialties of the physician who asserted malpractice, and the institutions where the physicians worked were examined in the case files. Due to the legal regulations in our country, the patients comprised those who had medicolegal preliminary evaluations after the patient's complaint made by an independent specialist physician and who were thought to require an advanced evaluation for malpractice by this preliminary examiner. The final result of the medicolegal process was not covered in the files.

\section{Statistical Analysis}

The Number Cruncher Statistical System (NCSS 2007) (Kaysville, Utah, USA) statistical software program was used for the statistical analysis and $p<0.05$ indicated statistical significance. The accordance of quantitative data to normal distribution was tested using the Shapiro-Wilk test and graphical examinations. The Mann-Whitney $U$ test was used for the comparison of two groups for quantitative data without normal distribution. The Kruskal-Wallis test was used to compare three or more groups for data that were not normally distributed, and the Bonferroni-Dunn test was used for mutual comparisons. For the comparison of qualitative data, the Fisher-Freeman-Halton test, Fisher's Exact test and Pearson's Chi-square test were used.

\section{RESULTS}

Based on the age distribution of the patients, the youngest age was detected as two days, the oldest as 16 years, and the median as nine years. TT occurred on the left side in 23 (43.4\%) patients, right side in 29 (54.7\%) patients, and bilaterally in one $(1.9 \%)$ patient. The mean of the torsion degrees detected during the exploration was 478.6 165.9 (range, 90-270) degrees. Descriptive characteristics of the patients during admission are reported in Table I. During the first

Table I. Distribution of patient characteristics

\begin{tabular}{llc}
\hline Age (years) & Min-max (median) & 2 days-16 years (9) \\
\hline Torsion side, $\mathrm{n}(\%)$ & Left & $23(43.4)$ \\
& Right & $29(54.7)$ \\
& Left+right & $1(1.9)$ \\
Admission symptom, $\mathrm{n}(\%)$ & Scrotal color change & $7(13.2)$ \\
& Scrotal swelling and pain & $34(64.2)$ \\
& Flank pain & $15(28.3)$ \\
Accompanying GIS symptom, $n$ (\%) & Inguinal region pain & $5(9.4)$ \\
& None & $35(66)$ \\
Accompanying GUS symptoms, $n$ (\%) & Present & $18(34)$ \\
& None & $44(83)$ \\
& Present & $9(17)$ \\
\hline *More than one was selected. GIS: Gastrointestinal system; GUS: Genitourinary system. &
\end{tabular}


admission, $12(22.6 \%)$ of the patients were evaluated by an urologist, $34(64.2 \%)$ by an emergency physician, and seven ( $13.2 \%)$ patients by a pediatrician. Scrotal examinations were performed for 42 (79.2\%) patients during the initial admission, and radiologic imaging examinations were performed for diagnosis in only 18 (34\%) patients (Fig. I).

Laboratory tests were performed in 26 (49.1\%) patients at the initial admission. Based on the test records, complete blood counts (CBC) were performed in 21 (80.8\%) patients and a complete urinalysis on the spot urine sample was performed in 15 (57.7\%). The physical examinations and radiologic imaging findings of the patients are summarized in Table 2.

When pre-diagnoses of the patients were examined, 31 (58.5\%) had epididymo-orchitis (EO), seven (13.2\%) had a urinary infection, five $(9.4 \%)$ had a hydrocele, four $(7.5 \%)$ patients had renal colic, and the others had testicle contusion, gastroenteritis, inguinal hernia, and acute appendicitis misdiagnoses. The mean delayed diagnosis time was detected as $59 \pm 11.2$ (range, 6-72) hours. A statistically significant relation was detected between the physician who first examined the patients and the execution condition of scrotal examination during the initial admission $(p=0.008 ; p<0.01)$. The ratio of physical scrotal examinations by emergency service physicians was lower than with urologists. No statistically significant relation was detected between the physician who first evaluated the patients and the scrotal examination findings in the subgroup analysis of patients who underwent physical examinations $(p>0.05)$. A scrotal pathology was found in $95.2 \%$ of patients who underwent scrotal examinations.

A statistically significant relation was detected between the physicians who evaluated the patients and imaging execution condition on initial admission ( $p=0.00 \mathrm{I} ; \mathrm{p}<0.0 \mathrm{I})$. The imaging execution ratio was higher in urologists compared with emergency service physicians and pediatricians. No statistically significant relation was detected between the evaluating physician and imaging methods and findings ( $p>0.05)$. After also considering the transferal of patients to the related specialties following the first evaluation, among the preliminary examiner allowed to be advanced evaluation for the possibili-

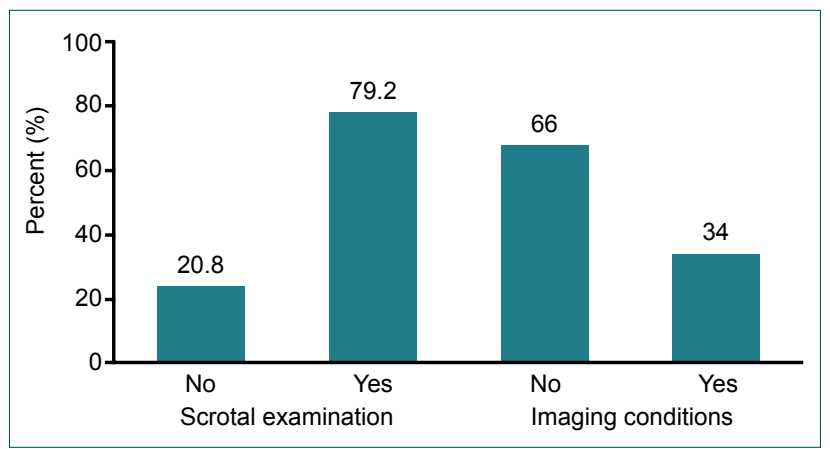

Figure 1. Distribution of scrotal examinations and imaging conditions on admission. ty of missing diagnosis by independent specialist physician, 25 (47.2\%) were urologists, 22 (4I.5\%) were emergency service physicians, four (7.5\%) were pediatricians, and two $(3.8 \%)$ were radiologists, respectively. A statistically significant difference was detected among the ratios of the physicians who missed the diagnosis $(p=0.001 ; p<0.01)$. Regarding the physician characteristics who were claimed to have missed the diagnosis, no statistically significant relation was detected between the physicians who missed the diagnosis and the institutions that missed the diagnosis $(p>0.05)$ (Table 3$)$. Based on the status of the institutions that missed the diagnosis, one (1.9\%) had primary healthcare status, 4 I $(77.3 \%)$ were secondary healthcare institutions (state hospitals), and II (20.8\%) were tertiary healthcare institutions (university hospitals or training and research hospitals). Among diagnosing the institutions, 26 (49.1\%) had secondary and 27 (50.9\%) had tertiary healthcare status.

Table 2. Distributions of the examinations that performed on admission

n $\%$

Physician who performed the first examination

$\begin{array}{lcc}\text { Urologist } & 12 & 22.6 \\ \text { Emergency department physician } & 34 & 64.2 \\ \text { Pediatrician } & 7 & 13.2\end{array}$

Scrotal examination condition

$\begin{array}{lll}\text { None } & \text { II } & 20.8 \\ \text { Present } & 42 & 79.2\end{array}$

Scrotal examination finding $(n=42)^{*}$

Normal

Scrotal swelling

Scrotal erythema

Scrotal sensitivity

Prehn sign

Imaging conditions

None $35 \quad 66$

Present

Imaging method $(n=18)$

Scrotal ultrasonography $5 \quad 27.8$

Scrotal Doppler

Imaging findings $(n=18)^{*}$

\begin{tabular}{lcc} 
Peritesticular hemorrhage & 3 & 16.7 \\
Vascularization is normal & 5 & 27.8 \\
Heterogeneity in scrotal parenchyma & 4 & 22.2 \\
Hypovascularization & 2 & 11.1 \\
Edema and dimensional increase in epididymis & 9 & 50 \\
Hydrocele & 4 & 22.2 \\
No vascularization & $\mathrm{I}$ & 5.6 \\
\hline
\end{tabular}

*More than one was selected. 
Table 3. The physician characteristics that were claimed to have missed the diagnosis

\begin{tabular}{|c|c|c|c|c|c|}
\hline & \multicolumn{4}{|c|}{ Physician who missed the diagnosis } & \multirow[t]{2}{*}{$\mathbf{p}$} \\
\hline & $\begin{array}{l}\text { Urologist } \\
(n=25)\end{array}$ & $\begin{array}{l}\text { ED physician } \\
\quad(n=22)\end{array}$ & $\begin{array}{c}\text { Pediatrician } \\
(n=4)\end{array}$ & $\begin{array}{l}\text { Radiologist } \\
(n=2)\end{array}$ & \\
\hline \multicolumn{6}{|c|}{ Scrotal examination condition during admission, $\mathrm{n}(\%)$} \\
\hline None & I (4) & $9(40.9)$ & I (25) & $0(0)$ & ${ }^{a} 0.008^{* *}$ \\
\hline Present & $24(96)$ & $13(59.1)$ & $3(75)$ & $2(100)$ & \\
\hline \multicolumn{6}{|c|}{ Scrotal examination finding, $n(\%)(n=42)$} \\
\hline Normal & $0(0)$ & $2(15.4)$ & $0(0)$ & $0(0)$ & ${ }^{\mathrm{a}} 0.319$ \\
\hline Scrotal swelling & $16(66.7)$ & $6(46.2)$ & $3(100)$ & $0(0)$ & ${ }^{\mathrm{a}} 0.086$ \\
\hline Scrotal erythema & I (4.2) & $0(0)$ & I (33.3) & $\mathrm{I}(50)$ & ${ }^{\mathrm{a}} 0.034^{*}$ \\
\hline Scrotal pain & $18(75)$ & $9(69.2)$ & $0(0)$ & $\mathrm{I}(50)$ & ${ }^{\mathrm{a}} 0.058$ \\
\hline Prehn sign & $3(12.5)$ & $2(15.4)$ & $2(66.7)$ & $0(0)$ & ${ }^{\mathrm{a}} 0.190$ \\
\hline Scrotal temperature increase & $6(25)$ & $3(23.1)$ & I (33.3) & $2(100)$ & ${ }^{\mathrm{a}} 0.183$ \\
\hline \multicolumn{6}{|c|}{ Imaging condition during admission, $\mathrm{n}(\%)$} \\
\hline None & $10(40)$ & $21(95.5)$ & $4(100)$ & $0(0)$ & ${ }^{\mathrm{a}} 0.00 \mathrm{I}^{* *}$ \\
\hline Present & $15(60)$ & I (4.5) & $0(0)$ & $2(100)$ & \\
\hline \multicolumn{6}{|l|}{ Imaging method, $n(\%)(n=18)$} \\
\hline Scrotal ultrasonography & $4(26.7)$ & I $(100)$ & - & $0(0)$ & ${ }^{\mathrm{a}} 0.324$ \\
\hline Scrotal Doppler & II (73.3) & $0(0)$ & - & $2(100)$ & \\
\hline
\end{tabular}

${ }^{a}$ Fisher-Freeman-Halton test; cMann-Whitney U Test. ${ }^{*} \mathrm{p}<0.05 * * \mathrm{p}<0.01$. ED physician: Emergency department physician.

\section{DISCUSSION}

TT is a urologic emergency among acute scrotal diseases because it requires urgent surgical intervention, and delays in the diagnosis and treatment phase may result in organ loss. [I] It is a clinical condition that should be handled carefully because of the results caused by wrong or late diagnosis on the patient, and also the medicolegal aspects for the physicians. For physicians involved in the diagnosis and treatment of acute scrotum, knowing about the management of the disease after its diagnosis and performing it according to medical terms prevents undesired results for patients, and recording and documenting all findings, examinations, and consultation results of the patient may prevent negative evaluations and results in medicolegal terms. ${ }^{[6]}$

Patients with TT are generally admitted to the hospital with sudden-onset and severe one-sided testicular pain. However, definitive diagnosis is difficult because the way the pain starts and the accompanying symptoms vary considerably. Acute EO is known as the first clinical condition that should be considered for the definitive diagnosis of acute scrotum in the literature. Although the most common pre-diagnosis was EO (58.5\%) for the patients in this study, clinical pre-diagnoses such as urinary infection (13.2\%), hydrocele (9.4\%), and renal colic $(7.5 \%)$, were also made. Due to the presence of the various clinical conditions that are covered in the definitive diagnosis of the disease, which is generally confused, detailed anamnesis and physical examination are very important for the correct diagnosis of TT. Thus, emergency service admission manner, pain characteristics, and distinction of accompanying symptoms of the patient are very important.

The presence of sudden-onset pain was reported by $96 \%$ of patients with TT and $50 \%$ of those with EO in the literature. [9] In the study conducted by Glabeke et al., ${ }^{[0]}$ sudden-onset pain was reported in $90.7 \%$ of patients diagnosed as having TT and $57.7 \%$ of patients with EO based on the evaluation of 543 patients admitted to the emergency department with acute scrotal pain. In the current study, sudden-onset pain was observed in only $29(54.7 \%)$ patients. When the fact that all of the patients resulted with testicle loss due to wrong or late diagnosis, it should be kept in mind that considering sudden-onset pain as a characteristic at admission may mislead the physicians at this stage of the diagnosis. This ratio being low compared with the literature makes the diagnosis harder in patients admitted with non-specific symptoms.

In the literature, regarding accompanying symptoms, it was reported that nausea and vomiting symptoms could accompany TT, EO, and appendix TT with a ratio of $32 \%, 12.5 \%$, and $3 \%$, respectively. ${ }^{[9,11-13]}$ It should be known that symptoms like those of the urinary system constitute another common cause of admission in this patient group. Cass et al. ${ }^{[14]}$ determined that the presence of urinary symptoms, such as frequent urination and/or dysuria, had an equal prevalence in 
patients with TT and EO (7\%). In our study, it was detected that $34 \%$ of patients had gastrointestinal system (GIS) syndromes and $17 \%$ had genitourinary system (GUS) symptoms; the presence of nausea-vomiting and/or urinary system symptoms among the accompanying symptoms did not contribute to the definitive diagnosis. Concerning pain localization, Anderson and Williamson reported that there were no scrotal symptoms in $5 \%$ of 597 patients with TT, $22 \%$ of patients had a stomach ache, which generally occurred before scrotal pain. ${ }^{[15]}$ In our study, $37.7 \%$ of the patients had a stomach ache and inguinal region pain during admission, which makes us consider that the advantage of pain localization is limited in the definitive diagnosis.

In addition to the anamnesis characteristics of the patients, the presence of physical examinations and their findings are also important. The ratio of patients who had scrotal examinations for diagnosis was $79.2 \%(n=42)$ in our study. It can be said that this ratio is low for TT, which is known to be diagnosed highly through clinical suspicion and physical examinations. The non-specificity of the symptoms in some patients and TT not coming to the physician's mind first in the diagnostic evaluation were evaluated as predisposing factors to missing the diagnosis. From this aspect, scrotal examination execution ratios of the patients, which constitute another finding acquired, were also different considering the physicians who first evaluated the patients. The physicians who first evaluated the patients were emergency service physicians with a ratio of $64.2 \%(n=34)$, urologists with $22.6 \%$ $(n=12)$, and pediatricians with $13.2 \%(n=7)$ and a statistically significant relation was detected between the physician who first evaluated the patient and scrotal examination execution condition during admission.

Scrotal examination execution ratios of emergency department physicians were lower than among urologists. The reason for the rather high scrotal examination performance ratio of urologists can be explained by that urologists consider urologic pathologies as a pre-diagnosis, and TT is considered first due to its important place among urologic emergencies, and the patients had been referred to urologists after the first evaluation. By contrast, emergency service physicians do not consider TT as a pre-diagnosis, and consequently, scrotal examination ratios were found lower among these physicians. Another interesting result acquired on physical examination findings was that a scrotal pathology was detected in $95.2 \%$ of patients who had scrotal examinations in the subgroup analysis of patients who had physical examinations. No statistically significant relation was detected between the physicians who first evaluated the patient and the scrotal examination findings. Given all these results, the high ratio of significant findings during physical examinations underlines the importance of physical examinations. In light of this information, it is important to raise TT and definitive diagnosis awareness of emergency department physicians who first evaluate patients during admission. Although the diagnosis of TT is generally made through clinical suspicion and the importance of physical examination has been emphasized, missing the diagnosis in the patients for which scrotal examination was executed in the study causes suspicion on the importance of physical examination alone in diagnosis.

Scrotal swelling, sensitivity, and erythema and edema are the known non-specific physical examination findings of TT and these findings can also be observed in patients with EO. ${ }^{[9,12,13,16]}$ Cass et al. ${ }^{\left[{ }^{[4]}\right]}$ reported that $68 \%$ of patients with TT and $20 \%$ of patients with acute EO had scrotal sensitivity and swelling, and $19 \%$ of patients with EO and 18\% of patients with TT had accompanying scrotal erythema. Twenty-eight (66.7\%) of the patients had sensitivity, $59.5 \%(n=25)$ had scrotal swelling, and $35.7 \%(n=15)$ had scrotal erythema in this series. Additional laboratory and imaging methods are used for the final decision in the diagnosis of TT because these findings are also present in other medical conditions that frequently cause misdiagnosis.

Imaging methods are frequently used in the diagnosis of TT, and the most commonly used imaging method is $\mathrm{CDU} \cdot[9,17,18]$ The imaging execution ratio of the patients was $34 \%$ in this study $(n=18)$, and CDU was performed in $72.2 \%(n=13)$ of these patients. This low imaging execution ratio is considered as one of the causes for diagnostic problems. A statistically significant relation was detected between the specialties of the physicians who first evaluated the patients and imaging condition during admission in our study. The imaging execution ratio was higher among urologists compared with emergency department physicians and pediatricians. This result supports that urologists consider TT more frequently. Although the role of CDU in TT diagnosis is controversial, there is a wide range of $63-100 \%$ for CDU sensitivity and $80-100 \%$ for CDU specificity in the diagnosis of TT in the literature. ${ }^{[3,4,19,20]}$ The blood flow of the affected testicle might be normal or increased in CDU imaging compared with the other testicle in $24 \%$ of patients with $\mathrm{TT}^{\left[{ }^{[3]}\right.}$ In our series, $27.8 \%$ of the patients who had CDU had normal testicle vascularization, and findings that could be interpreted as EO were observed in $50 \%$ of the patients. ${ }^{[5,9]}$ Given these findings, normal or increased blood flow in the affected testicle and the detection of findings that can be interpreted as EO emphasize the specificity deficiency of CDU in the diagnosis of TT and therefore should not cause the definite exclusion of a TT diagnosis.

Physicians in the primary management of TT differ in various conditions. The variability of physicians to whom the patients were first admitted and consultation with different specialties of physicians and performing imaging when required can be stated among the most important reasons for this. When diagnostic problems occur due to these multiple evaluations and a retrospective evaluation is demanded in medicolegal terms, there may be differences in the branches of physicians against whom prosecutions were started. In a study on TT 
malpractice by an insurance company in the United States of America, urologists were reported among the mostly accused physicians. ${ }^{[21]}$ In another study, emergency department physicians were reported as the mostly accused physicians in TT malpractice with a ratio of $48 \%$, and urologists were accused with a ratio of $23 \% .{ }^{[22]}$ When the referral of patients to related specialties of physicians following the first evaluation was considered in our study, among the physicians against whom a prosecution was allowed, $47.5 \%(n=25)$ were urologists, $41.5 \%(n=22)$ were emergency department physicians, $7.5 \%$ $(n=4)$ were pediatricians, and $3.8 \%(n=2)$ were radiologists. Based on these results, among the branches participating in the TT diagnosis and treatment phase, which demands a multidisciplinary approach, emergency department physicians, who have the highest ratio among the physicians who first evaluate these patients, and urologists as the specialty primarily dealing with TT, are mostly accused in malpractice cases. Based on the number of patients with inadequate CDU results in diagnostic terms, the number of radiologists held responsible for an incomplete diagnostic phase for whom further investigations began was lower than among the other specialties. This result shows that radiologists are held less responsible for the inadequacy of CDU in the diagnosis of TT and the subsequent outcomes. Thus, physicians are generally held responsible for problems in the diagnosis of TT because it is a clinical diagnosis.

The lack of a control group, the limited number of patients in the Forensic Medicine Institution archives, and patients with TT who were unreachable or were not subjects of legal actions between the mentioned years can be mentioned among the limitations of this study. Some of the data may be missing or incorrect because the information and findings for the patients were acquired from case files.

\section{Conclusion}

Problems occurring in the diagnosis and treatment phase of TT continue despite all the improvements in the medical field. Physicians should perform the required evaluations for a suitable diagnosis and treatment by putting aside their medicolegal concerns and prevent problems by giving priority to patient health. As a result, studies should be performed to increase the information levels of physicians for the correct diagnosis and proper management of TT, and patients should be explored urgently in the event of clinical suspicion because time is very important in the treatment phase.

Ethics Committee Approval: Approved by the local ethics committee.

\section{Peer-review: Internally peer-reviewed.}

Authorship Contributions: Concept: A.I.T., Y.B.; Design: A.I.T.; Supervision: A.I.T., Y.B.; Resource: Y.B., N.Y.; Materials: Y.Ç., Y.O.D., N.Y.; Data: Y.Ç., Y.O.D., Y.A., N.Y.; Analysis: Y.Ç., Y.O.D., Y.A.; Literature search: Y.Ç., Y.O.D., Y.A. Writing: Y.Ç., Y.O.D.; Critical revision: A.I.T. ,Y.B., N.Y.
Conflict of Interest: None declared.

Financial Disclosure: The authors declared that this study has received no financial support.

\section{REFERENCES}

1. Mansbach JM, Forbes P, Peters C. Testicular torsion and risk factors for orchiectomy. Arch Pediatr Adolesc Med 2005;159:1167-71. [CrossRef]

2. Liang T, Metcalfe P, Sevcik W, Noga M. Retrospective review of diagnosis and treatment in children presenting to the pediatric department with acute scrotum. AJR Am J Roentgenol 2013;200:W444-9. [CrossRef]

3. Kalfa N, Veyrac C, Lopez M, Lopez C, Maurel A, Kaselas C, et al. Multicenter assessment of ultrasound of the spermatic cord in children with acute scrotum. J Urol 2007;177:297-301; discussion 301. [CrossRef]

4. Lewis AG, Bukowski TP, Jarvis PD, Wacksman J, Sheldon CA. Evaluation of acute scrotum in the emergency department. J Pediatr Surg 1995;30:277-82. [CrossRef]

5. Davenport M. ABC of general surgery in children. Acute problems of the scrotum. BMJ 1996;312:435-7. [CrossRef]

6. Zhao LC, Lautz TB, Meeks JJ, Maizels M. Pediatric testicular torsion epidemiology using a national database: incidence, risk of orchiectomy and possible measures toward improving the quality of care. J Urol 2011;186:2009-13. [CrossRef]

7. Kulchavenya E. Best practice in the diagnosis and management of urogenital tuberculosis. Ther Adv Urol 2013;5:143-51. [CrossRef]

8. Selbst SM, Friedman MJ, Singh SB. Epidemiology and etiology of malpractice lawsuits involving children in US emergency departments and urgent care centers. Pediatr Emerg Care 2005;21:165-9. [CrossRef]

9. Waldert M, Klatte T, Schmidbauer J, Remzi M, Lackner J, Marberger M. Color Doppler sonography reliably identifies testicular torsion in boys. Urology 2010;75:1170-4. [CrossRef]

10. Van Glabeke E, Khairouni A, Larroquet M, Audry G, Gruner M. Acute scrotal pain in children: results of 543 surgical explorations. Pediatr Surg Int 1999;15:353-7. [CrossRef]

11. Beni-Israel T, Goldman M, Bar Chaim S, Kozer E. Clinical predictors for testicular torsion as seen in the pediatric ED. Am J Emerg Med 2010;28:786-9. [CrossRef]

12. Lyronis ID, Ploumis N, Vlahakis I, Charissis G. Acute scrotum -etiology, clinical presentation and seasonal variation. Indian J Pediatr 2009;76:407-10. [CrossRef]

13. Mushtaq I, Fung M, Glasson MJ. Retrospective review of paediatric patients with acute scrotum. ANZ J Surg 2003;73:55-8. [CrossRef]

14. Cass AS, Cass BP, Veeraraghavan K. Immediate exploration of the unilateral acute scrotum in young male subjects. J Urol 1980;124:829-32.

15. Anderson JB, Williamson RC. Testicular torsion in Bristol: a 25-year review. Br J Surg 1988;75:988-92. [CrossRef]

16. Mäkelä E, Lahdes-Vasama T, Rajakorpi H, Wikström S. A 19-year review of paediatric patients with acute scrotum. Scand J Surg 2007;96:62-6.

17. Mellick LB. Torsion of the testicle: it is time to stop tossing the dice. Pediatr Emerg Care 2012;28:80-6. [CrossRef]

18. Yagil Y, Naroditsky I, Milhem J, Leiba R, Leiderman M, Badaan S, et al. Role of Doppler ultrasonography in the triage of acute scrotum in the emergency department. J Ultrasound Med 2010;29:11-21. [CrossRef]

19. Kadish HA, Bolte RG. A retrospective review of pediatric patients with epididymitis, testicular torsion, and torsion of testicular appendages. Pediatrics 1998;102:73-6. [CrossRef]

20. Karmazyn B, Steinberg R, Kornreich L, Freud E, Grozovski S, Schwarz M, et al. Clinical and sonographic criteria of acute scrotum in children: a retro- 
spective study of 172 boys. Pediatr Radiol 2005;35:302-10. [CrossRef]

21. Matteson JR, Stock JA, Hanna MK, Arnold TV, Nagler HM. Medicolegal aspects of testicular torsion. Urology 2001;57:783-7. [CrossRef]
22. Colaco M, Heavner M, Sunaryo P, Terlecki R. Malpractice Litigation and Testicular Torsion: A Legal Database Review. J Emerg Med 2015;49:849-54. [CrossRef]

\section{ORIJINAL ÇALIŞMA - ÖZET}

\section{Adli tıp perspektifinden testis torsiyonu: Tanı neden eksik?}

Dr. Ali İhsan Taşçı, ${ }^{1}$ Dr. Yavuz Onur Danacıoğlu, ${ }^{1}$ Dr. Yunus Çolakoğlu, ${ }^{1}$

Dr. Yusuf Arıkan, ${ }^{1}$ Dr. Nur Yalçınkaya, ${ }^{2}$ Yalçın Büyük ${ }^{2}$

${ }^{1}$ Bakırköy Dr. Sadi Konuk Eğitim ve Araştırma Hastanesi, Üroloji Kliniği, İstanbul

${ }^{2}$ Türkiye Cumhuriyeti Adli Tıp Kurumu, İstanbul

AMAÇ: Medikolegal açıdan sorun oluşturmuş testis torsiyonu (TT) olgularını inceleyerek, bu gibi durumlarda tıbbi ihmal veya yanlış uygulamaya neden olmuş belirteçleri tanımlamak ve testis torsiyonu olgularının tıbbi yönlerini karakterize etmek amacıyla bir inceleme yaparak sizlere sunmayı amaçladık.

GEREÇ VE YÖNTEM: 2004-2019 yılları arasında Türkiye'nin farklı hastanelerinde gerçekleştirilmiş müdahaleler sonucu, orşiektomi olan ve Türkiye Cumhuriyeti Adalet Bakanlığı Adli Tıp Kurumu'nda tıbbi uygulama hatası bakımından incelenen 53 testis torsiyonu olgusuna ait veriler geriye dönük olarak değerlendirildi.

BULGULAR: Olguların median yaşı dokuz yıldır. Torsiyon olguların \%43.4'ünün ( $n=23)$ sol tarafında, \%54.7'sinin ( $n=29)$ sağ tarafında, \%।.9'unun $(n=I)$ ise iki taraflı testis torsiyonu izlenmiştir. Ön tanılar incelendiğinde; \%58.5 ( $n=31)$ epididimorşit, \%।3.2 ( $n=7)$ üriner enfeksiyon, \%9.4 ( $n=5)$ hidrosel, \%7.5 $(n=4)$ renal kolik ve diğer ön tanılar testis kontüzyonu, gastroenterit, inguinal herni ve akut apandisit olarak saptanmıştır. Başvuru

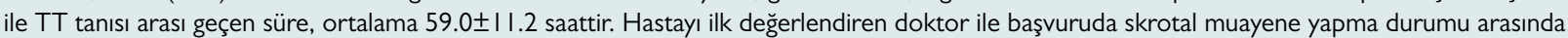
istatistiksel olarak anlamlı ilişki saptanmıştır ( $p=0.008 ; p<0.0$ I). Acil servis hekimlerinde skrotal muayene yapma oranı ürologlardan düşüktür. Malpraktis açısından bağımsız bir uzman tarafından ileri incelemeye gerek görülen ve adli tıp kurumuna gelen hasta dosyalarında suçlanan hekimler; 25 (\%47.2) üroloji uzmanı, 22 (\%4l.5) acil servis uzmanı, dört (\%7.5) pediatrist ve iki (\%3.8) radyoloji uzmanıydı.

TARTIŞMA: Hekimler medikolegal kaygılarından önce hasta sağlığı açısından bu aksaklılıkların mümkün olduğu yaşanmaması için doğru tanı ve tedavi için gerekli değerlendirmeleri yapmalıdır. Doğru tanı için hekimlerin bilinçlendirilmesi, hekimlerin bilgi ve bilinç düzeyinin arttırılması ve sürecinin zamana karşı olması nedeniyle klinik olarak şüphe edilmesi halinde hastanın acil ameliyat edilmesi uygun gözükmektedir.

Anahtar sözcükler: Akut skrotum; malpraktis; medikolegal; testis torsiyonu; yanlış tanı.

Ulus Travma Acil Cerrahi Derg 2021;27(2):207-213 doi: 10.14744/tjtes.2020.68339 